\title{
PELATIHAN PENANGANAN LIMBAH BATANG SINGKONG MENGGUNAKAN MESIN PERAJANG BATANG SINGKONG (RABAKONG) DI DESA TANJUNG BULAN, KECAMATAN KASUI , WAY KANAN
}

\author{
Sandi Asmara*, Sapto Kuncoro, Iskandar Zulkarnain \\ Jurusan Teknik Pertanian FP Universitas Lampung, Bandar Lampung \\ Jl. Prof. SumantriBrojonegoro No.1 Bandar Lampung 35145 \\ Penulis Korespodensi : Shandiasmara@yahoo.com
}

\begin{abstract}
Abstrak
Limbah batang singkong di Provinsi Lampung sangat banyak dan belum termanfaatkan, bahkan keberadaannya menjadi masalah dimasyarakat, karenanya perlu dicarikan solusi penanganannya. Permasalahannya hingga saat ini masyarakat belum menemukan peralatan pembantu untuk mengolah limbah tersebut sehingga limbah tersebut belum tertangani dengan baik dan menguntungkan. Unila sebagai salah satu perguruan tinggi di Lampung mensikapi hal tersebut dengan melakukan penelitian perancangan alat perajang batang singkong (Rabakong, sehingga saat ini sudah terwujud. Mensikapi permasalahan diatas maka keberadaan alat ini perlu untuk disosialisasikan penggunaannya agar masyarakat mengetahui manfaat dan kegunaannya, terutama dalam menjawab permasalahan yang dihadapinya. Untuk itulah kegiatan pengabdian masyarakat ini dilakukan. Metode yang dilakukan dalam kegiatan ini adalah Three in One, yang mengayomi tiga aspek kegiatan dalam satu rangkaian kegiatan, yaitu bersih, teruji dan menguntungkan. Secara umum hasil pengabdian ini sangat diterima oleh masyarakat karena mereka menemukan solusi yang menguntungkan dalam menangani limbah batang singkong. Karenanya, dalam pelaksanaan kegiatan ini masyarakat sangat antusias menerimanya. Terwujudnya beberapa produk pupuk organik, pakan ternak dan briket dalam penanganan limbah ini memberi motivasi masyarakat dalam mengembangkan materi yang diberikan. Harapan kedepan dalam penanganan limbah ini akan mampu dihasilkan produk-produk turunan lain yang bernilai tambah dan bersifat ekonomis agar mampu memberi peluang pendapatan masyarakat dalam berbudidaya singkong, seperti, papan komposit, obat nyamuk, pot organik dan lain-lain.
\end{abstract}

Keywords: Limbah Batang Singkong, Rabakong, Pengecilan ukuran, Produk turunan

\section{Pendahuluan}

Singkong merupakan salah satu produk pertanian tanaman pangan yang dihasilkan Provinsi Lampung. Keberadaannya tersebar hampir diseluruh kabupaten/kota, menjadikan Provinsi Lampung sebagai produsen singkong terbesar di Indonesia. Menurut data BPS Lampung (2017), produksi singkong yang dihasilkan Provinsi Lampung sebesar 8,45 juta ton, setara dengan share sebesar $35,33 \%$ untuk produksi keseluruhan Republik ini.

Dengan jarak tanam 1 x 1 meter akan dihasilkan 10.000 tanaman tiap hektarnya, artinya akan dihasilkan 10.000 batang singkong pada saat panen. Jika 1 batang setelah dipotong untuk bibit rata-rata berbobot $0,4 \mathrm{~kg}$ (hasil penimbangan, 2017), maka akan dihasilkan 4 ton limbah batang singkong/hektar. Di Provinsi Lampung luas lahan singkong mencapai 342.100 ha (BPS Lampung,
2017), artinya secara umum di Lampung akan dihasilkan limbah biomassa batang singkong sebanyak $1.368,4$ ton/tahun.

Kondisi tersebut merupakan suatu tantangan menarik yang perlu segera mendapatkan solusi dalam penanganan dan pemanfaatan limbah tersebut. Bagaimana cara untuk merubah limbah biomassa batang singkong agar bisa dimanfaatkan menjadi produk yang lebih bermanfaat dan bernilai tambah merupakan solusi yang perlu dipikirkan. Selama ini penanganan dan pemanfaatan limbah biomassa batang singkong hanya dibuang atau dibakar saja oleh petani, karena ketidak tahuan mereka dalam memanfaatkannya. Keberadaannya dilahan bahkan menjadi tempat bersarangnya tikus, hama dan penyakit yang merugikan pertumbuhan tanaman singkong. 


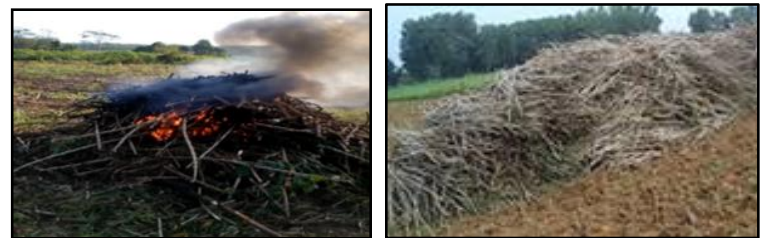

Gambar 1. Pembakaran dan pembuangan limbah batang singkong dilahan.

Untuk memanfaatkan limbah biomassa batang singkong menjadi berbagai produk lain yang bernilai ekonomis perlu dilakukan upaya pengecilan ukuran. Permasalahan utama yang hingga kini dirasakan petani dalam mengelola limbah batang singkong adalah belum diketahuinya metode/teknik untuk melakukan pengecilan ukuran batang singkong yang efektif. Sampai saat ini pengecilan hanya dilakukan dengan cara pemotongan atau pencincangan batang singkong dalam ukuran yang masih besar dan kasar belum bisa halus. Karenanya pemanfaatannya belum bisa diwujudkan menjadi suatu produk yang bernilai tambah. Hal ini yang menyebabkan petani belum termotivasi untuk menangani dan mengelola limbah biomassa batang singkong tersebut, yang pada akhirnya keberadaan limbah batang singkong ini hanya dibiarkan, dibuang atau dibakar saja dilahan.

Permasalahan diatas pada akhirnya mengilhami perlunya upaya menyebarkan dan memanfaatkan keberadaan alat perajang batang singkong mekanis (Rabakong) yang sederhana, praktis, mudah untuk diproduksi dan dikembangkan. Alat tersebut mampu menghasilkan rajangan batang singkong dalam bentuk serbuk halus sebagai bahan baku memproduksi beberapa produk turunan yang bernilai tambah, seperti: pupuk organik, pakan ternak, briket atau papan komposit.

Dengan memanfaatkan alat perajang batang singkong serta dihasilkannya berbagai produk turunan tersebut diharapkan masyarakat akan lebih tertarik untuk memanfaatkan dan mengelola limbah biomassa batang singkong. Hal ini secara tidak langsung akan menyadarkan dan memotivasi mereka untuk membersihkan lahannya dari keberadaan limbah batang singkong dan menjadikannya sebagai peluang usaha baru untuk meningkatkan pendapatannya. Keterpaduan terwujudnya kedua produk tersebut diharapkan mampu mempercepat proses hilirisasi produk mesin perajang batang singkong di masyarakat.
Tujuan pengabdian adalah: 1) mensosialisasikan keberadaan Rabakong sebagai alat untuk mengecilkan ukuran limbah batang singkong hingga menjadi bentuk serbuk halus. 2) memberikan solusi pada upaya penanganan limbah batang yang keberadaannya menjadi masalah bagi masyarakat menggunakan alat Rabakong. 3) memberikan pengetahuan dan ketrampilan masyarakat dalam memanfaatkan, mengoperasikan, merawat dan memperbaiki alat Rabakong. 4) memberikan ketrampilan masyarakat membuat produk turunan limbah batang singkong yang bernilai tambah (pupuk organik, pakan ternak, briket).

Manfaat pengabdian adalah: 1) sebagai upaya membuka wawasan petani dalam menangani masalah keberadaan limbah batang singkong secara zero waste:. 2) memberikan sumbangan pemikiran dalam pengembangan teknologi penanganan dan pengelolaan limbah batang singkong secara terpadu dan menguntungkan; 3) Memberikan alternative dan peluang usaha lain dalam budidaya singkong berupa penciptaan produk turunan yang bernilai tambah; 4) memperkuat upaya hilirisasi pemanfaatan mesin Rabakong di masyarakat dan 5) memotivasi masyarakat/petani untuk bersemangat membersihkan limbah batang singkong melalui penggunaan mesin Rabakong yang mampu menghasilkan bahan baku untuk membuat produk bernilai tambah/ekonomis dan menguntungkan.

\section{Bahan dan Metode}

Bahan yang dipergunakan untuk pembuatan:

a. Pupuk Organik: serbuk batang singkong, dolomit, urea, MOL (mikroorganisme lokal), dan cocodust.

b. Pakan ternak: serbuk batang singkong, urea, onggok, tebon jagung terfermentasi, daun singkong, molases dan Premix

c. Briket bahan bakar: batubara, serbuk batang singkong, tepung kanji.

Metode yang dipergunakan adalah pelatihan dan praktek. Pelatihan dimaksudkan untuk memberikan informasi iptek secara tertulis dan penjelasan lisan terkait materi yang dibahas, diantaranya tentang: teknik mengumpulkan bahan baku limbah batang singkon, pengertian pengecilan ukuran, sekilas tentang Rabakong, pupuk organik, pakan ternak, limbah dan teknik penanganannya. Praktek yang dimaksud adalah menyampaikan materi melalui proses pengecilan ukuran dan 
pembuatan produk secara langsung membuat bersama masyarakat, sehingga masyarakat mampu melaksanakannya.

Untuk memecahkan masalah penanganan limbah batang singkong konsep yang dikembangkan adalah "Three in One". Dalam konsep ini upaya menyelesaikan masalah dan harapan dilakukan dengan menerapkan tiga bentuk pemberdayaan masayarakat dalam satu kesatuan rangkaian kegiatan pengabdian masyarakat. Pemberdayaan pertama adalah meningkatkan kemampuan dan ketrampilan masyarakat dalam menangani limbah batang singkong dengan cara mamberikan pengetahuan dan praktek mengumpulkan limbah batang singkong, teknik menyusun yang baik ditempat pengumpulan serta pemanfaatan alat Rabakong untuk mengecilkan batang singkong menjadi serbuk batang singkong (yang untuk selanjutnya akan dijadikan bahan baku berbagi produk turunan bernilai tambah, pupuk organik dan pakan ternak). Kedua, meningkatkan kemampuan dan ketrampilan masyarakat dalam membuat produk turunan dari serbuk pelepah sawit yang bernilai tambah. Ketiga, meningkatkan kemampuan masyarakat dalam manajemen pengelolaan dan pemasaran produk turunan yang dihasilkan (pupuk organic, pakan ternak, briket) sebagai upaya pengembangan usaha peningkatan pendapatan masyarakat dengan mengkomersialkan produk turunan yang dihasilkan di desa Ogan Lima, Kecamatan Abung Barat, Lampung Utara.

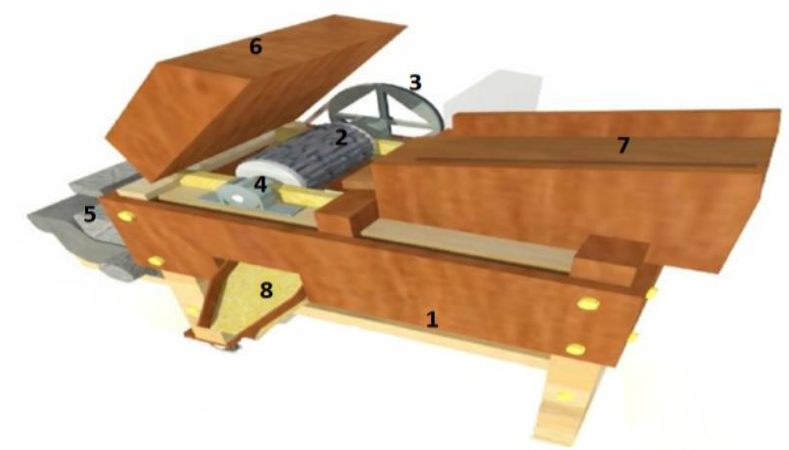

Keterangan:

1. Kerangka; 2. Bagian Perajang; 3. Pulley dan Vanbelt; 4. .Pillow Block; 5). .Motor penggerak 6. Penutup Perajang 7.Meja Pengumpan 8. Pengeluaran

Gambar 2. Alat Rabakong

\section{Hasil dan Pembahasan}

A. Pelatihan Memilih dan Mengumpulkan Limbah Batang Singkong.
Pelatihan ini berkaitan dengan bagaimana memilih dan mengumpulkan limbah tersebut untuk dimanfaatkan menjadi pupuk organik, pakan ternak dan briket. Hal ini agar masyarakat mampu memilih bahan baku yang sesuai untuk dijadikan bahan pakan ternak, pupuk organik dan briket. Untuk bahan baku yang masih segar dan baru akan lebih baik dimanfaatkan sebagai bahan baku pakan ternak. Untuk bahan baku limbah yang sudah kering bisa dimanfaatkan sebagai pupuk organik.
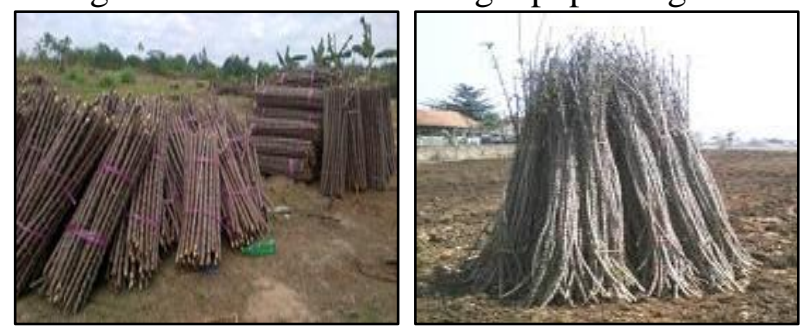

Gambar 3. Teknik pengumpulan bahan baku

Dari hasil pelatihan ini $100 \%$ peserta mampu melaksanakan pemilihan dan melakukan proses pengumpulan bahan baku dengan benar dan efektif sehingga memudahkan penanganan lebih lanjut.

\section{B. Pelatihan dan Praktek Pengenalan Komponen Alat Rabakong dan Fungsinya.}

Pelatihan dan praktek tentang materi ini dimaksudkan agar masyarakat mengetahui dan memahami bentuk, fungsi dan cara kerja dari masing-masing komponen alat penyusun Rabakong (seperti terlihat pada gambar 2).

\section{Alat Perajang}

Bagian yang berfungsi sebagai tempat merajang batang singkong menjadi bagian-bagian yang lebih $\mathrm{kecil} / \mathrm{halus}$ dan seragam.

\section{Pulley dan v-belt}

Pully berfungsi sebagai penerus putaran dari poros motor bakar menuju alat perajang sedangkan sabuk v-belt berfungsi sebagai alat transmisi putaran dan tenaga dari motor bakar menuju bidang alat perajang.

\section{Pillow block}

Pillow block berfungsi untuk mengurangi gesekan antara as dan rumahnya sehingga alat dapat berputar dengan stabil.

\section{Motor Bakar/Sumber Tenaga Penggerak}


Bagian yang menghasikan sumber tenaga penggerak dalam pengoperasian alat perajang batang singkong.

\section{Penutup Perajang Batang Singkong}

Penutup ini berfungsi agar pada saat proses perajangan hasil rajangan tidak bertaburan.

6. Meja Pengumpan Batang Singkong

Berfungsi untuk meletakkan danmemperlancar proses pengumpanan batang singkong pada alat perajang.

\section{Saluran keluaran}

Merupakan komponen yang berfungsi sebagai lorong saluran keluarnya hasil rajangan /cacahan batang singkong setelah batang singkong mengalami proses perajangan.

\section{B. Pelatihan dan Praktek Pengecilan Ukuran Batang Singkong.}

Pelatihan ini memberikan pengetahuan masyarakat tentang cara mengecilkan ukuran limbah batang singkong menjadi bentuk serbuk halus. Pelatihan dilakukan secara mekanis menggunakan alat Rabakong, seperti gambar 4.

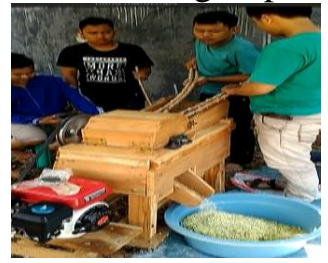

Gambar 4. Proses pengecilan ukuran
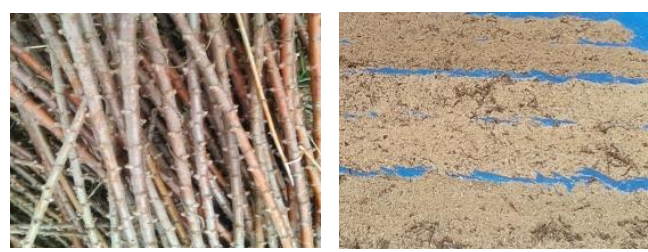

Gambar 5. Perubahan wujud batang singkong menjadi serbuk batang singkong

Dalam pelatihan dan praktek pengecilan ukuran ini semua peserta mampu melaksanakan dan menguasai kinerja alat dengan baik. Masyarakat sangat antusias mempraktekannya karena menemukan solusi yang sesuai dengan harapan mereka untuk menangani keberadaan limbah batang singkong dilahannya.

Dalam kegiatan pengecilan ukuran selanjutnya, serbuk yang dihasilkan bisa dipisahkan menjadi 3 (tiga) bentuk ukuran, yaitu: 0,2, 0,2-0,5 dan $>0,5 \mathrm{~cm}$ seperti terlihat pada gambar 6 .
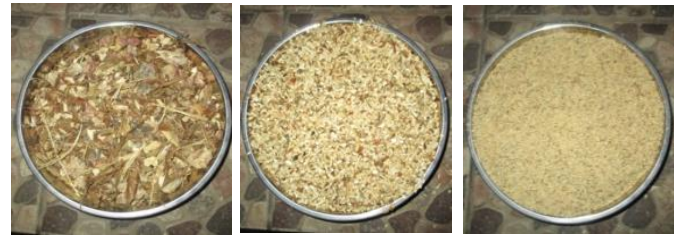

Gambar 6. Berbagai ukuran serbuk batang singkong yang dihasilkan

\section{Pelatihan Pembuatan Pupuk Organik}

Pelatihan ini dimaksudkan agar masyarakat mampu membuat pupuk organik dengan memanfaatkan limbah batang singkong dilahannya. Selain sebagai upaya membersihkan lahan, hal ini juga dimaksudkan untuk memberikan peluang usaha bagi masyarakat dengan memproduksi pupuk organik yang juga dibutuhkan dalam usaha tani sawit.

Komposisi pupuk organik yang dipraktekkan adalah sebagai berikut:

Tabel 1. Komposisi pupuk organik

\begin{tabular}{cccccc}
\hline $\begin{array}{c}\text { Serbuk btg } \\
\text { singkang } \\
(\mathrm{kg})\end{array}$ & $\begin{array}{c}\text { Tinja } \\
\text { sapi } \\
(\mathrm{kg})\end{array}$ & $\begin{array}{c}\text { Dolomit } \\
(\mathrm{kg})\end{array}$ & $\begin{array}{c}\text { Urea } \\
(\mathrm{gr})\end{array}$ & $\begin{array}{c}\text { Cocadust } \\
(\mathrm{gr})\end{array}$ & $\begin{array}{c}\text { MUL } \\
(\mathrm{ml})\end{array}$ \\
\hline 70 & 30 & 1 & 500 & 500 & 200 \\
\hline
\end{tabular}

Cara Pembuatan pupuk organik dari limbah batang singkong adalah: a) menyiapkan hamparan terpal plastik tempat mencapur bahan; b) mencampur semua bahan diatas menjadi satu kecuali MOL dan aduk secara merata; c) Mencampur $200 \mathrm{ml}$ MOL dengan 5 liter air kemudian sebarkan secara merata diatas campuran bahan tadi dan aduk secara homogen; d) tutup campuran tersebut dengan terpal secara rapat; e) simpan selama 20-30 hari dengan 5 hari sekali dibuka.; f) jika sudah tidak berbau maka pupuk organik sudah jadi.
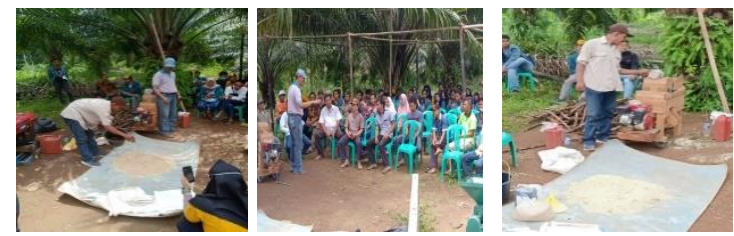

Gambar 7. Proses pembuatan pupuk organik

Dalam praktek pembuatan pupuk organik peserta sangat antusias menerima materi. Hal ini dikarenakan pupuk organik salah satu produk yang sangat dibutuhkan dalam berbudidaya sawit. Apalagi pupuk organik bisa dihasilkan dari pemanfaatan limbah pelepah sawit yang selama ini mengganggu mereka keberadaannya dilahan. 
Secara umum peserta mampu membuat sendiri pupuk organik dari bahan baku pelepah sawit dan merasa sangat puas dengan produk pupuk organik yang dihasilkan, seperti gambar 10 .

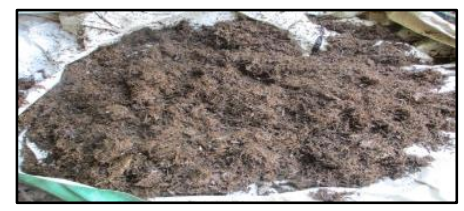

Gambar 8. Pupuk organik yang dihasilkan peserta

\section{Pelatihan Pembuatan pakan Ternak}

Pelatihan ini dimaksudkan untuk memberi pengetahuan dan ketrampilan masyarakat peserta untuk mampu membuat pakan ternak sendiri dengan memanfaatkan limbah pelepah sawit. Produk pakan ini sangat dbutuhkan juga oleh masyarakat, karena jika beli sangat mahal dan pada musim kering mereka sulit mencari pakan dari hijaun. Karenanya adanya pelatihan ini mereka sangat antusias menerima dan mempraktekannya.

Komposisi pakan yang dipraktekkan adalah sebagai berikut:

Tabel 2. Komposisi bahan pakan

\begin{tabular}{lc}
\hline \multicolumn{1}{c}{ Bahan Pakan } & Imbangan \% \\
\hline Onggok & 30 \\
Bungkil sawit terfermentasi & 35 \\
Cacahan Batang singkong & 15 \\
Tebon jagung terfermentasi & 15 \\
Daun singkong & 0 \\
Molases & 2 \\
Urea & 1 \\
Premix & 1 \\
\hline JUMLAH & $\mathbf{1 0 0}$ \\
\hline
\end{tabular}

Cara pembuatan pakan ternak adalah dengan mencampur semua bahan baku menjadi satu dan mengaduknya secara merata. Pakan ternak yang dipraktekkan merupakan pakan ternak yang langsung bisa dikonsumsi oleh hewan ternak baik sapi maupun kambing.

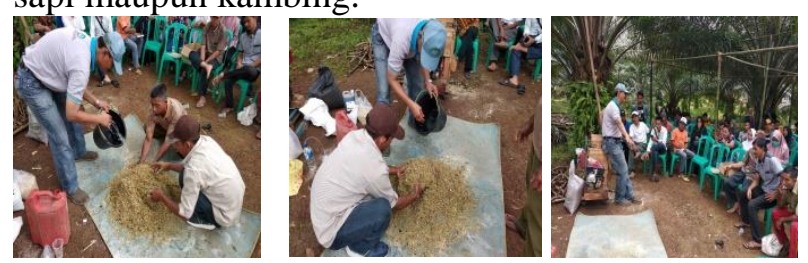

Gambar 9. Praktek pembuatan pakan ternak
Dalam pembuatan pakan ternak tersebut semua peserta mampu mengerti, memahami dan membuat pakan sendiri dari bahan pelepah sawit. Dengan beragamnya biomassa yang ada diwilayah kecamatan Kasui, menginspirasi masyarakat untuk membuat berbagai produk pakan dengan berbagai komposisi yang bisa dibuat. Hal ini menjadi tolok ukur bermanfaatnya pengetahuan yang diabdikan pada mereka.

\section{E. Pelatihan dan Praktek pembuatan Briket}

Salah satu produk yang bisa dibuat dari limbah batang singkong adalah briket bahan bakar. Produk ini merupakan produk yang sangat dibutuhkan juga oleh masyarakat di Kecamatan Kasui karena bisa mengganti kebutuhan bahan bakar minyak maupun gas LPG. Briket adalah bahan bakar padat sebagai sumber energi alternatif pengganti bahan bakar minyak yang melalui proses karbonasi kemudian dicetak dengan tekanan tertentu baik dengan atau tanpa bahan pengikat (binder) maupun bahan tambahan lainnya..

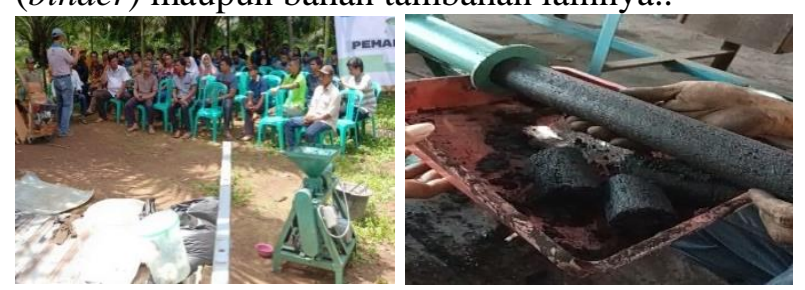

Gambar 10. Praktek pembuatan briket

Dalam praktek pembuatan briket komposisi bahan yang digunakan seperti terlihat pada gambar 11 dibawah ini.

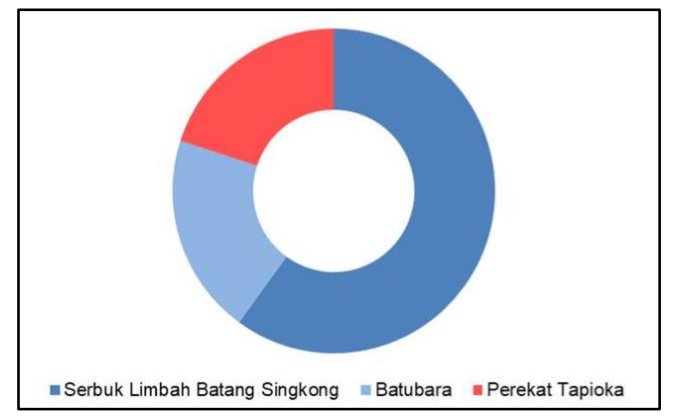

Gambar 11. Komposisi bahan pembuat briket

Cara pembuatan briket seperti terlihat pada gambar 12 dibawah ini 


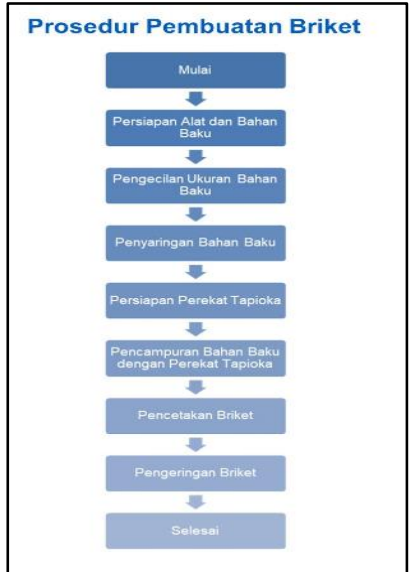

Gambar 12. Prosedure pembuatan briket

AdapunSpesifikasi briket yang dihasilkan seperti terlihat pada gambar 13.

\begin{tabular}{|l|c|}
\hline \multicolumn{1}{|c|}{ Parmeter } & Nilai \\
\hline Kadar Air (\%bb) & $<8$ \\
\hline Kerastan (g'm) & $0.44-0.50$ \\
\hline $\begin{array}{l}\text { Kebuatm Tekm } \\
\text { (bgim) }\end{array}$ & $40-150$ \\
\hline $\begin{array}{l}\text { Nilai Kalor } \\
\text { (bkalkg) }\end{array}$ & $>4500$ \\
\hline $\begin{array}{l}\text { Water Resistance } \\
\text { Index (\%) }\end{array}$ & $40-60$ \\
\hline $\begin{array}{l}\text { Impact Resistance } \\
\text { Index (\%) }\end{array}$ & $>90$ \\
\hline $\begin{array}{l}\text { Laju Pembakarm } \\
\text { (gimenit) }\end{array}$ & $0.1-05$ \\
\hline
\end{tabular}

Gambar 13. Spesifikasi briket batang singkong

\section{Kesimpulan}

Dari hasil pengabdian yang dilakukan dalam penanganan dan pemanfaatan limbah pelepah sawit di Kecamatan Kasui Kabupaten Way Kanan ternyata masyarakat sangat antusias menerima materi yang disampaikan dan berkehendak untuk mengembangkannya setelah pengabdian selesai.

Kesesuaian muatan pengetahuan dan teknologi dengan potensi limbah pelepah saawit yang menjadi masalah bagi masyarakat merupakan kunci keberhasilan dari pengabdian ini. Hal ini terutama dalam penerapan teknologi pengecilan ukuran, fermentasi dan pencampuran.

Terwujudnya pupuk organik, pakan ternak dan Briket bahan bakar serta teknologi penanganan limbah batang singkong yang dipraktekkan mampu juga dibuat oleh masyarakat. Hal ini menunjukkan keberhasilan pelaksanaan pengabdian yang dilaksanakan.

Karenanya, untuk kedepan pengabdian yang berbasis penelitian dan penerapan iptek yang sesuai perlu dikembangkan. Adanya pendampingan dalam penerapan iptek di masyarakat perlu dipikirkan terutama dalam mewujudkan terbentuknya industri-industri kecil produk yang bernilai tambah hasil pemanfaatan limbah biomassa, seperti: pupuk organik, pakan ternak, briket dan lain-lain.

\section{Ucapan Terima Kasih}

Ucapan terima kasih disampaikan pada BPKKN Unila yang telah memberi kesempatan pada kami melaksanakan pengabdian masyarakat dalam kegiatan KKN mahasiswa Unila Periode I 1/2019 bulan Januari 2019 di Kecamatan Kasui Kabupaten Way Kanan. Hal ini dikarenakan adanya kegiatan KKN mahasiswa, permasalahan dimasyarakat khususnya desa Tanjung Bulan , Kecamatan Kasui, Kabupaten Way Kanan. dapat memperoleh solusi melalui penerapan iptek hasil penelitian Unila. Demikian pula dengan pihak aparatur Desa Tanjung Bulan maupun Kecamatan Kasui yang berkenan memberi ijin untuk terlaksananya pengabdian ini.

\section{Daftar Pustaka}

Agustini, N. 2010. Petunjuk Praktis Manajemen Pengelolaan Limbah Pertanian untuk Pakan Ternak Sapi. Balai Pengkajian Teknologi Pertanian. Balai Besar Pengkajian dan Pengembangan Teknologi Pertanian. Badan Penelitian dan Pengembangan Pertanian. Kementrian Pertanian. Jakarta.

Arif, Y dan Hasrul, A.H. 2012. Pemanfaatan Limbah Padat dan Cair Untuk Pupuk di Perkebunan Kelapa Sawit. Sawit Media Edisi 5/IX/2012. Pusat Penelitian Kelapa Sawit (PPKS). Medan

Muhtarudin dan Yusuf, 2010. Optimalisasi Pemanfaatan Limbah kelapa Sawit Dalam Upaya Integrasi Ternak-Sawit. Makalah Pengabdian Masyarakat Program Klinik Pertanian FP Unila di Lampung Tengah.

Muhtarudin, 2011, Peluang Penggunaan Daun Kelapa Sawit Sebagai pakan ternak Ruminansia. Kumpulan Materi Pelatihan Pengolahan Pakan Dari Limbah Pertanian /Perkebunan Dinas Peternakan dan Kesehatan Hewan Propinsi Lampung. Bandar Lampung.

Nurhayu. A, A.B. L Ishak, dan Andi Ella.

Sudaryanto, B. 2008. Peluang Penggunaan Daun Kelapa Sawit sebagai Pakan Ternak 
Ruminansia. Proseding Seminar Nasional Peternakan dan Veteriner. Balai Penelitian Ternak. Bogor

Sukandar. 2012. Konsep Desa Mandiri. Bahan Kuliah FIA UB, Malang

Sianipar, T.P. 2009. Efek Pelepah Daun Kelapa Sawit dan Limbah Industrinya sebagai Pakan terhadap Pertumbuhan Sapi Peranakan Ongole Pada Fase Pertumbuhan. Skripsi. Fakultas Pertanian, Universitas Sumatera Utara, Medan Syamsu Jasmal A, 2010. Daya Dukung Limbah Pertanian Sebagai Sumber Pakan Ternak Rminansia Di Indonesia. Bulletin Peternakan Indonesia. 